EDUCATION

Research, Inovortion and Solutions on-line ${ }^{(8)}$
PSYCHOLOGY

$1+D+i$
Electronic Journal of Research

in Educational Psychology

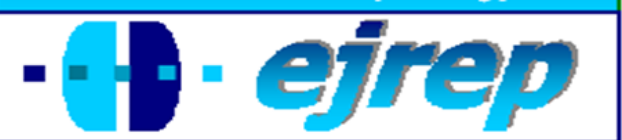

Editorial EOS

\title{
Towards Self-regulated Academic Writing: an exploratory study with graduate students in a situated learning environment
}

\author{
Montserrat Castelló $^{1}$, Anna Iñesta ${ }^{1}$, Carles Monereo ${ }^{2}$ \\ ${ }^{1}$ Faculty of Psychology, Ramon Llull University, Barcelona \\ ${ }^{2}$ Dpt. Educational Psychology, Autónoma University of Barcelona, Barcelona
}

\section{Spain}

Correspondence: Montserrat Castelló. Facultat de psicología, ciències de l'educació i de l'esport. Blanquerna. Universitat Ramon Llull. C/Císter, 34. 08022. Barcelona. Spain. E-mail: montserratcb@,blanquerna.url.edu

(C) Education \& Psychology $\mathrm{I}+\mathrm{D}+\mathrm{i}$ and Editorial EOS (Spain) 


\begin{abstract}
Introduction. In the last few decades, writing has been considered as a situated process inserted in a specific communicative situation. This implies that texts are characterized by them incorporating the different voices of the texts they dialogue with, so they cannot possibly considered as isolated products.

Method. In this paper we present an exploratory study whose objective is to know the difficulties and effective strategies which 19 doctoral students use when regulating the writing process of their academic texts. This study analyzes students' knowledge about their own composition process as well as the emotions attached to it, their conceptions about academic writing, the revision strategies which are present in the different drafts produced of each of the texts, and the quality of their final version.

Results. The results show that regulation and text quality are related with the writers' ability to associate their difficulties with explicit solutions and strategies. The students' efforts and interest in making their voice visible in the texts as well as their awareness about their own writing process are related with text quality and with some specific changes observed in the drafts, related with voice and modality. Affective variables and, especially, anxiety were always present in the students' reports but no significative correlations were found between this feeling and text quality or the use of specific revision strategies.

Discusion and Conclusions. The results obtained allow us to confirm that, in line with recent studies, the students who show less awareness about their writing process feel more anxious during that process. Moreover, very few of these students showed personal and explicit writing objectives, and they incorporated very few new strategies to their revision process.
\end{abstract}

Keywords: academic writing; undergraduate education; writing regulation; higher education; collaborative writing revision

Received: 06/15/09 Initial Acceptance: 06/17/09 Final Acceptance: 09/14/09 


\section{Hacia la escritura académica autorregulada: un estudio explo- ratorio con estudiantes posgraduados en un entorno de aprendizaje situado}

\section{Resumen}

Introducción. En las últimas décadas, la escritura se viene considerando como un proceso situado que se inscribe en una situación comunicativa específica. Esto implica que los textos se caracterizan por incorporar las distintas voces de los textos con los que dialoga, de manera que resulta imposible concebirlos de forma aislada.

Método. Se trata de un studio exploratorio que pretende conocer las dificultades y estrategias efectivas que 19 estudiantes de doctorado utilizan a la hora de regular el proceso de escritura de sus textos académicos. Este estudio analiza el conocimiento que los estudiantes tienen sobre su proceso de composición así como las emociones asociadas al mismo, sus concepciones sobre la escritura académica, las estrategias de revisión presentes en los diferentes borradores de los textos, y la calidad de la versión final de los mismos.

Resultados. Los resultados revelan que la regulación y la calidad de los textos están relacionadas con la capacidad de los escritores para relacionar sus preocupaciones con soluciones y estrategias explícitas. Los esfuerzos y el interés de los estudiantes para hacer su voz visible en sus textos así como su consciencia sobre su propio proceso de escritura están relacionados con la calidad del texto y con algunos cambios específicos en los borradores, relacionados con la voz y la modalidad. Las variables afectivas y, especialmente, la ansiedad estuvieron siempre presentes en los informes de los estudiantes pero no se hallaron relaciones significativas entre este sentimiento y la calidad del texto o el uso de estrategias específicas en la revisión del mismo.

Discusión y Conclusiones. Los resultados obtenidos nos permiten confirmar que, de acuerdo con studios recientes, los estudiantes que se muestran menos conscientes sobre su propio proceso de escritura se sienten más ansiosos durante el mismo. Además, muy pocos de estos estudiantes mostraron objetivos de escritura personales y explícitos, y se mostraron poco ágiles a la hora de incorporar nuevas estrategias a su proceso de revisión.

Palabras Clave: Escritura académica, auto-regulación escritura, doctorado; educación superior, revisión colaborativa

Recibido: 15/06/09 Aceptación inicial: 17/06/09 Aceptación final: 14/09/09 


\section{Introduction}

Research about the writing process has changed since the groundbreaking studies of Flower \& Hayes (1980) or Bereiter \& Scardamalia (1987) which, developing from previous traditions (Emig, 1977), popularized the differences between expert and novel writers, revealing the complexity of the cognitive processes involved in expert composition. Over the last few years, the expert writing process has ceased to be understood as "that to be followed" and, thanks to the contribution of fields such as pragmatics or sociolinguistics, together with socio-cognitive psychology and psycholinguistics, it is now common to consider that writing a text is a situated process which is embedded in a specific communicative situation (Camps \& Castelló, 1996; Englert, Mariage \& Dunsmore, 2006; Flower, 2002). This implies, as Bakhtin suggested (1986), that every text, and even more so every academic text, incorporates or should incorporate the voices of other previous texts to which it aims to respond and, at the same time as it expects other texts to do the same with respect to itself. It is in this sense that we can understand the composition process as being in some way dialogic and multivoiced, being impossible to conceive it in isolation from the textual production that surrounds it (Dysthe, Samara \& Westrheim, 2006).

Obviously, this is a diferred dialogue whose specific characteristics make it different from oral dialogue. Among such characteristics, the impossibility for the writers to share time and space with their interlocutors stands as one of the most important ones. This forces them to very clearly emphasize the knowledge they consider to be shared with the readers, at the same time as they relate this knowledge to the new information provided by the same author (van Dijk \& Kintsch, 1983).

Moreover, in the effort of making new and shared knowledge explicit, writers must make their voice, frequently distant from those of others, visible and justify its legitimacy and originality despite the common use of citations or impersonal forms (Ivanic, 1998). From the above follows that it is very unlikely that an "ideal composition process" exists and that it is more adjusted to reality to conceive writing as a flexible, dynamic and diverse process which changes according to the communicative situations which compel us to write. This means that writing is always situated and the process followed by a given author can solely be interpreted according to the network of particular conditions that every setting configures. 
This way of characterizing the composition processes better adjusts to the descriptions of our activity as writers, being more pertinent than that proposed by the models exclusively emphasizing the cognitive aspects or by those focusing on social and pragmatic aspects, with the consequent analysis of the final products (Camps \& Milian, 2000; Castelló, 2000; Pittard \& Martlew, 2000).

\section{Strategies to manage and regulate writing}

Most of the instructional proposals addressing academic writing at the university aim to promote the students' acquisition of strategies that allow them to efficiently manage and regulate their own composition process. Ultimately, their objective is to have students reflect upon their intention and objectives when writing every particular text, and to have them regulate their composition process so as to fulfil these objectives (Caffarella \& Barnett, 2000; Carlino, 2006; Castelló, 2000; Englert, Mariage \& Dunsmore, 2006; Graham, 2006; Tynjäläe, Mason \& Lonka, 2001).

University students have already incorporated strategies which allow them to solve writing demands associated to tell what they already know, but most of them have not learned how to manage more complex demands which require them to adjust the knowledge of their own rhetoric and discursive objectives so as to produce complex academic texts (Castelló, 1999; Castelló, Iñesta, Miras, Sole, Teberosky \& Zanotto, 2007). This may not have been even necessary given that most of the common academic tasks can be solved without much reflection. However, it is unlikely that a text such as the doctoral dissertation, a research project or an academic paper can be written without such strategies (Caffarella \& Barnett, 2000; Carlino, 2006). Precisely, one of academic writers' main objectives when elaborating a paper is to reorganize their own knowledge by accessing deeper levels of relation between the concepts and thereby produce new knowledge (Lonka 2003).

Such an objective cannot be fulfilled merely by applying any planning or revising techniques, or by being familiar with the macrostructures of each academic genre. In the last few years, research has shown that objectives, conceptions, writers' identity as well as consciousness about their own composition process are key in writing regulation (Torrano \& González, 2004; Efklides, 2006; MacArthur, Graham, Fitzgerald, 2006; Bartels, MagínJackson, Kemp, 2009). We can hypothesise, therefore, that this regulation depends on the relation between three groups of variables which play a mutually influencing role in the com- 
position process: representation of the communicative situation, writer's knowledge, and the already read and written text/s.

Taking this framework into account, we can say that the teaching and learning of writing strategies should allow students to know and analyze both their representations and activity in those socially situated settings where they will be required to be communicative agents. Therefore, regarding the doctoral students' teaching and learning process, we consider that:

- Making a strategic use of academic writing implies helping students become progressively independent thinkers and develop their identity as writers (Englert, Mariage \& Dunsmore, 2006 ; Tynjäläe et al. 2001)

- The strategies to regulate one's own writing cannot be taught and/or learned without having in mind the specificity of the communicative situation and the content one must write about (Flower, 2002; Hyland, 2000; Hyland and Tse, 2004)

- Teaching these strategies should promote the students' reflection regarding: a) the content they are writing about and the establishment of new conceptual relations; b) the decisionmaking processes before, during and after the writing process; c) the affective and identity-related aspects that stem out from writing academic texts (Ivanic, 1998; Pittard \& Martlew, 2000)

These considerations integrate an explanatory model of the writing activity that becomes a working hypothesis in the research projects we develop.

This model integrates the classic subprocesses of planning, textualization and revision, which take place recursively during composition depending on the interaction between the proposed variables: the representation of the communicative situation, the different types of students' knowledge, and the source texts that accompany the writer as well as the new text. In the following sections we briefly comment on these variables.

\section{a. Representation of the communicative situation}

We are perfectly aware that the notion of "representation" may have different meanings, as it has been widely discussed in Educational Psychology during the last twenty years, but taking into account the objectives of this paper, it may be useful to synthesize and focus on two broad meanings. On the one hand, representation refers to the possibilities in designing the notational means, which make it possible to symbolise certain facts, phenomena or languages "externally". On the other hand, we may talk about "representation" to refer to "in- 
ner" schemata (or frameworks, codes, traits, images, etc.) used when interacting with the world and with ourselves. In this paper, the idea of representation is taken from this second perspective $^{1}$.

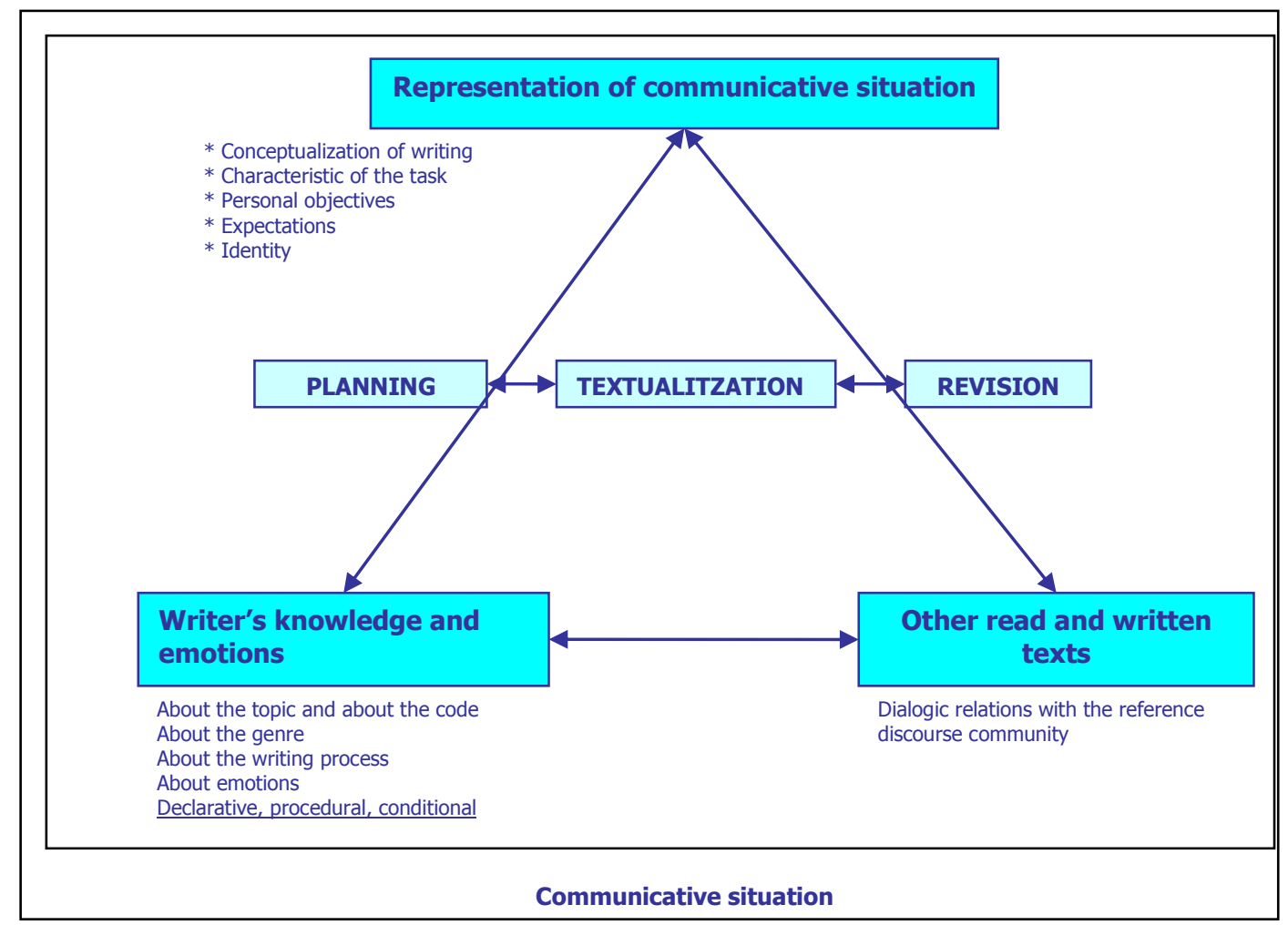

Figure 1. Explanatory model of the regulation processes in writing

The final mental representation of a specific text will be the result of a creative and constructive activity in which the variables of each specific situation interact with the writer's previous representations about writing, coming from his/her participation in former communicative situations. Do writers think, for example, that they must explain in their own words what they have read or, conversely, that they must make their voice be heard? Between these two poles there exists a wide spectrum of representations that implies conceptualizing the communicative situation in a progressively more complex and personal manner. This requires students to have clear and personal objectives and to solve a rhetoric problem: manage to

\footnotetext{
${ }^{1}$ We also know that writing can activate a wide range of mental representations at different levels (more or less accessible to consciousness) and about different contents (linguistic, thematic, cognitive...), and still we can distinguish some stable and quite permanent representations (e.g. schematas), not directly linked to any particular situation, from those situated and dynamic representations, that is to say, depending on the specific communicative situation demands, constructed taking into account these socio-cognitive demands and modified according to some variation perceived in the communicative situation (Vosniadou, 1994).
} 
have readers understand and share their own viewpoint. Depending on the writers' representation of the communicative situation a different composition process will begin (with more or less previous work of planning, with more or less need to revise, with more or less anxiety, etc.). This claim is supported by the results of different studies with primary school, high school and university students whose results showed how the students' representations of the different academic tasks modulated both their objectives and the strategies used when writing. The most sophisticated strategies, high levels of planning and revision and the existence of personal objectives only appeared when they interpreted that the writing objective was clear and interesting (Castelló, 1999; Lavelle \& Zuercher, 2001; MacArthur, Graham, Fitzgerald, 2006; Nelson, 1990; Pajares \& Valiante, 2006).

\section{b. Writer's knowledge}

The second of the variables that play a key role in writing process regulation has to do with the knowledge that the writers activate when they compose according to their representation of the communicative situation. This knowledge includes knowledge about the topic, knowledge about the composition process, and the strategies necessary to manage it, also including linguistic, rhetoric and textual knowledge. Research usually considers the first (topic knowledge), and authors insist on the importance of linguistic and rhetoric resources (Hyland $\&$ Tse, 2004). Both are necessary but not sufficient in academic writing situations. It is also necessary to advance in our knowledge of the strategies to regulate the composition process which allow writers to efficiently control its complexity and to fulfill their own objectives.

\section{c. Other texts and the written text}

Finally, we must take into account those texts already produced -by the writer as well as by authors who may be considered representative of the academic community- to insert the present writing in a dialogic context. Paying attention to the characteristics that the new text gradually acquires (regarding the possibility of it being understood, contested, ignored, taken into consideration, etc.) implies paying attention to them at the very same moment of text production, at the same time as we have in mind those texts we wish to interact with (Pittard \& Martlew, 2000). 


\section{Dissertation writing workshop: a proposal to promote doctoral students' self-regulated writing}

For more than six years now, and as part of the Doctoral Program at the Graduate School of Psychology Blanquerna (Barcelona) we have developed an instructional proposal called Dissertation Writing Workshop with the objective of helping students progress according to the following objectives:

1. to acquire knowledge about the most relevant characteristics of the academic texts and their composition process

2. to become aware of their own writing process and assess their own competences and difficulties

3. to analyze and acquire the strategies necessary to write academic texts

4. to know and analyze the specificities of the academic context where doctoral dissertation and academic texts are inscribed

5. to become conscious of the academic writer identity and the emotions associated to his/her development

6. to develop positive and useful attitudes towards academic production and the formative and social relations it implies

With the objective of ensuring reflection processes, the workshop is organized in two kinds of sessions: some are teacher-directed, where the students work on different activities, and some other sessions have students work collaboratively in dyads, having the opportunity of engaging in peer-revision processes which allow them to analyze their own progress from their peers' comments ${ }^{2}$.

Individual work is reflected in the compilation of a portfolio which includes the personalization of the suggested objectives as well as the evidences that such objectives are being fulfilled. The evidences include:

\footnotetext{
${ }^{2}$ For more details about the workshop, interested readers could consult: Castelló, M. (2008). Usos estratégicos de la lengua en la universidad. Tácticas de regulación de la escritura en estudiantes de doctorado. En A. Camps y M. Milian (Coords.) Miradas y voces. Investigación sobre la educación lingüistica y literaria en entornos plurilingües (75-90). Barcelona: Graó.
} 
1. Text assessing each of the sessions. This is an argumentative text.

2. Writing process diary. Writing it involves reflecting about the composition process in each of the individual writing sessions and includes at least the following: time devoted to writing, reference material consulted, quantity of text produced, perceived satisfaction and steps followed when writing (first, secondly..).

3. Complete text written by the students as part of their doctoral studies (research article, chapter of a research project or doctoral dissertation, etc). Students are asked to write an authentic text and it is the same student who chooses it according to his/her needs and expectations (urgency, difficulty, interest, etc.). It is normally the case that students choose the dissertation project or a chapter of the research project they are asked to work on before they engage in the doctoral dissertation.

4. Traces of revisions in the different drafts of the text as they are marked with the word processor option "track changes".

5. Analysis and comments of a peer who plays the role of "external revisor".

\section{Characteristics of Doctoral Students' Regulation Processes: An Exploratory Study}

The exploratory study we summarize below was designed so as to fulfill two general objectives: investigating which are the main difficulties and also success in doctoral students' acquisition of writing regulation strategies, during their participation in a dissertation writing workshop as the one described above, and exploring the relationship between the variables of the presented model which will need to be contrasted in future research studies.

More specifically our objectives were:

a. to describe the difficulties and effective strategies in students' regulation of their writing process

b. to explore how emotional and cognitive factors interact during the writing process

c. to relate traces of writing process regulation with the quality of final text

d. to analyze how students who are more conscious of their own writing process regulate it as well as the feelings associated with it 


\section{Method}

\section{Participants}

Participants were two class groups attending the Dissertation writing workshop in the 2004-2005 and 2005-2006 academic years. Each of the groups was formed by 15 students. The overall sample contained 30 students ( 22 females and 8 men) with a mean age of 25.3 years old.

\section{Instruments and Variables Analyzed}

The data were collected from different sources and instruments including:

- Open-ended survey at the beginning of the workshop, addressing three main areas: (a) students' knowledge about writing; (b) representation about writing their specific project; (c) emotions and goals associated to writing. The survey was adapted from Lonka's writing questionnaire $(1996 ; 2003)$ and the students' answers were analysed -as Lonka proposed- in a qualitative way. We used content analysis with the Atlas.ti software, and we established categories which comprised all the students' comments.

- Diary: As we have already said, each student wrote a diary after every writing session in which they were asked to reflect upon the time devoted to the writing session, what they had done (first, second...), the degree of satisfaction with the work done, and the reasons why they felt that way. The comments included in the diary were also analysed using Atlas.ti and then categorised

- Drafts of all written texts, including the changes made during each writing session as they had been marked with the Track Changes tool of the word processor. For the analysis of the drafts we used previously set categories concerning the types of changes writers introduce when revising texts (Sánchez, García \& Del Río, 2002). We initially considered five categories -voice, modality, guidance, added information and precision- and after a first analysis we included a new category -self-directed clues- in order to collect those comments concerning clues or indications the writer directs to him/herself to be considered in following drafts.

- The quality of the final written text. We used a 10-item scale developed in previous studies (Castelló \& Monereo, 1996) to assess expository and argumentative texts. Three independent and trained judges assessed the texts (15-20 pages length) and the reliability coeffi- 
cients for all items were high (kappa >.79). Where differences occurred, the final value was agreed by the judges reviewing and discussing these differences.

Procedures

After informing the students, we obtained their consent to participate in the study. Throughout the Dissertation writing workshop all evidence of the work carried out by the students was photocopied and then different systems were designed to analyze the variables. Once compiled, all the qualitative data were analyzed and categorized by three researchers who discussed them until consensus was reached in all the cases. Finally, statistical analyses were made concerning students' representations, text quality and revision of the drafts.

\section{Design and statistical analysis}

Design was descriptive and exploratory and the study was developed in authentic settings. It focused on the multiple cases analysis and data triangulation. Qualitative and quantitative data were collected regarding the participants' representation of the communicative situation, their goals and expectations, the characteristics of their writing process, and the cognitive and emotional problems perceived during the composition process. Finally, we considered the overall quality of the written texts. Statistical analyses were made to explore the relationship between the different variables along the process (SPSS), and discourse analysis allowed us to analyze the students' representations and explanations about their writing process (ATLAS-ti).

\section{Results}

Concerning our first objective -to describe the difficulties and effective strategies in student's regulation of their writing process- we distinguish between what students say and what they really do. Figure 2 shows the results regarding students' reflections along the workshop which are, moreover, supported by their actions. Results, refer to those students' explicit reflections and comments (extracted from their diaries) which were translated into actions being visible in their drafts. 


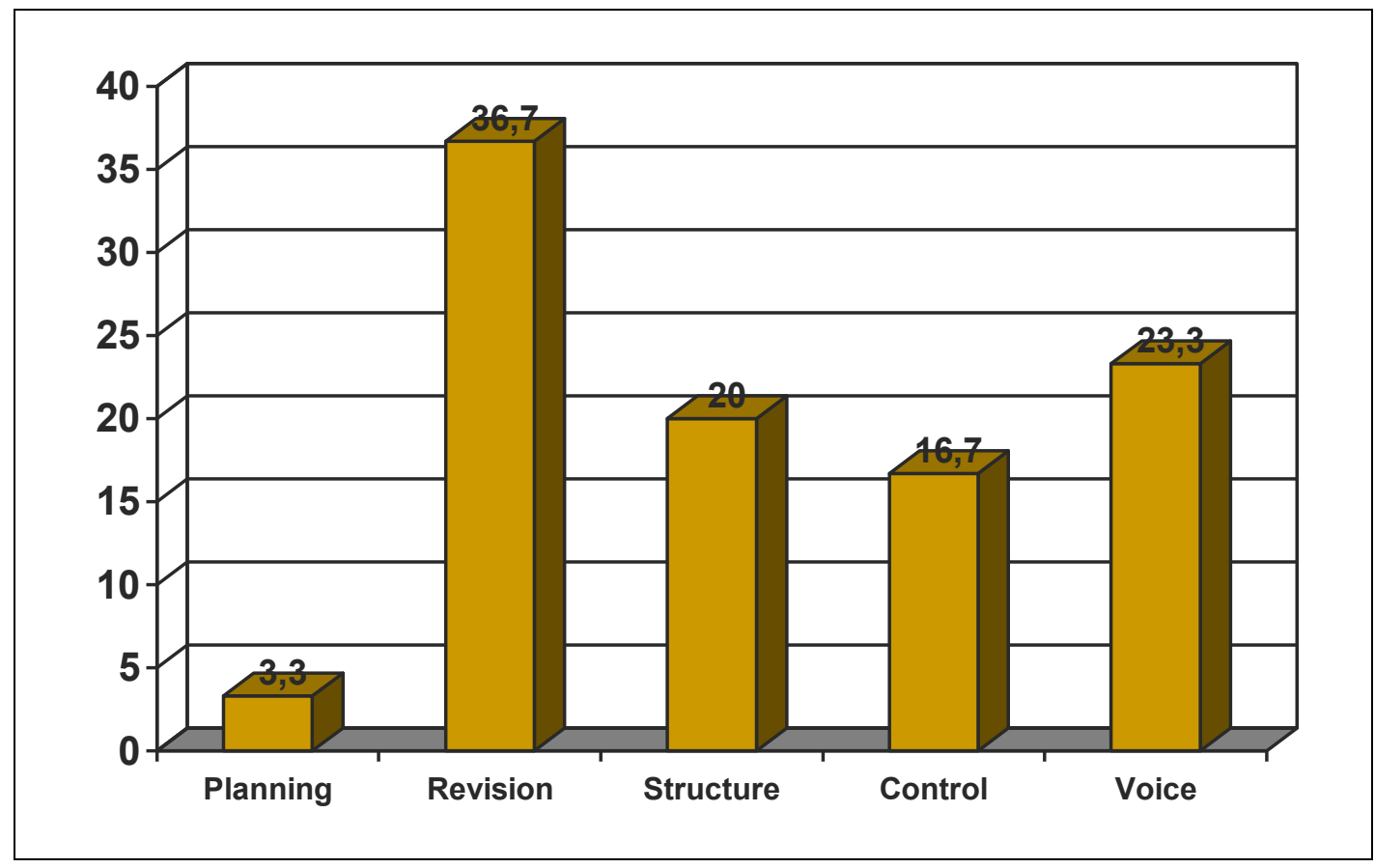

\section{Figure 2. Percentage of students' comments concerning their own writing process confirmed in drafts}

The students' comments can be grouped in five broad categories, each of them being more complex than the former in such a way that placing a student in a given category means that $\mathrm{s} /$ he knows and uses the procedures which also pertain to the previous one. We briefly describe below the main characteristics of such categories, illustrating them with some representative examples of the type of data they include.

\section{Planning}

This category includes the comments and actions related with the elaboration of a general plan of the text, an outline, a brain-storm, etc. These are procedures which help create and make explicit a precise and personal representation of the task to be solved. They usually involve establishing writing objectives that go beyond preoccupation for content, including the rhetorical aspects of the communicative situation.

Results are surprisingly low in this category; as a possible explanation to this data, we can point out that the instruments used for data collection may have imprinted a bias to the results given that, as we already commented on, we only took into consideration those comments 
students made about their composition process which could then be supported by following drafts. Local planning, which takes place on-line, is not reflected through the "track changes" tool of the word processor, because this tool only makes the changes introduced after saving the first version of a text visible.

The following comment illustrates those who integrated this category:

"I believe that I finally realized that my anxiety decreases when I know clearly the "skeleton" of what I want to say. I have managed it today, and once overcome the initial anxiety, the process is hard but faster. I still don't know how to revise. It is difficult for me to find the problems that the text may have"

\section{Revision}

In agreement with what we pointed out, this is the category which registered most of the students' comments and actions (36.7\%). It includes different types of revision, from the modification or suppression of lengthy paragraphs to the revision of grammar, lexical choice and spelling. Most of these changes have to do with intentional processes of revision of the same text - or of any of its sections - and, consequently, they allow us to infer in some degree the implicit planning processes. In this sense, it seems plausible to suppose that it is necessary to construct some kind of representation of the text to be written that becomes a reference point when initiating revision processes. We have not included here those revisions whose objective is to analyze the structure of the text according to the writer's objectives, which are included in the following category.

The following comment illustrates those who integrated this category:

"I have reread and corrected it afterwards, after some rest. This has been the axis of the work. This has been a critical moment, where the maturity of the text, grammatical form, and style became more prominent. Satisfaction has increased as well..."

\section{Structure}

This category includes, as we commented above, those comments or actions that imply reflection upon the structure of the text and that are only possible when the writer takes into account the rhetoric problem involved in adjusting content to his/her own writing objectives. 
This is, therefore, an advanced level of reflection upon the process which obviously implies the existence of planning and revision activities. $20 \%$ of the students' comments and actions fell in this category. The following example illustrates some of these comments:

"Today, for the first time, I stopped writing before finishing all I wanted to say. I have decided that it was better not to add aspects such as..., because they were not clearly related with the main thesis"

\section{Control}

Within this category we have included those comments and actions which consciously aim at writing regulation with the objective that the produced text adjusts to the requirements of the communicative situation. Regulation at this level implies the existence of writer's own objectives, of a personal representation of the task which adjusts to the communicative situation and the management of cognitive and affective processes along the composition process. $16.7 \%$ of the students showed evidences of effecting this kind of control as they progresses through the workshop sessions, and the following example can illustrate the kind of comments they made in their diaries:

"I have realized that when I get blocked the best I can do is come back to the objective, rethink what I intended and then reread. Not only reread because then I get more blocked still”

Voice

This is the most complex category in our analysis and it corresponds to those comments and actions which, apart from involving a similar degree of control over the process to that included in the previous category, show a preoccupation with making their voice visible in the academic text. In this sense, then, the comments show the writers' willingness to include their personal imprint onto the text. Thus, they are capable of maintaining the argumentative tension of academic texts which, despite adjusting to a precise and set structure, manage to interest and adhere the readers by deliberately using resources such as discourse markers, guidance paragraphs, explanatory sentences or paragraphs, comments designed to make explicit the decisions involved in the writing process, etc. Ultimately, this category reveals the construction of the students' identity as writers that very few doctoral students show and that is a requirement to publish academic texts. 
It is difficult to provide brief comments which are representative of this category since most of the times one must study their diaries and contrast their comments with the changes introduced in their texts to interpret them. Some of their comments reflect ideas such as the following:

"When I know what I want to say, I make an effort to put the ideas into words, to then give them form (this way, I don't forget any of them). When I start giving them form, I find many problems not to be repetitive and, at the same time, not to give any aspect for granted." "I find it difficult to find the balance where my intention will be visible without becoming too much of a pain."

Twenty-three point three of the students showed evidence of this kind of reasoning, a certainly high percentage if we have in mind the difficulties it involves and the few novice writers who can regulate their writing in this way (Boscolo \& Mason, 2001; Tynjaelae et al., 2001)

We also analysed students' drafts and the changes they introduced in each new version of their text. This kind of microanalysis showed the evolution of their writing processes as well as the aspects they paid more attention to when revising. Categories with a great amount of changes were Modality and Precision in those three levels analysed (lexical, syntactic and structure)

Regarding the changes introduced in every successive draft, no significant differences were found between the three drafts analysed for each subject in precision and modality categories (Precision $\chi 2=1.105$; p: .575; modality $\chi 2=5.314$; p: .070). Thus, we can not claim for a progression in revising regarding those categories. However, differences were found in selfdirected clues which are lower in each new draft. Students showed more self-directed clues in the first draft than in the third one specially concerning aspects of syntaxes and structure (SdcSintactic $\chi^{2}=8.375 ; \mathrm{p}: .015 \mathrm{~S}-\mathrm{dcStructure} \chi^{2}=5.69 ; \mathrm{p}$ : .058). Moreover, students who held that writing is a matter of telling knowledge were those who introduce more changes in their drafts only concerning syntactic precision (Mann-Whitney $U .=1.19 ; \mathrm{p}=.046$ ).

As for our second objective, in order to explore how emotional and cognitive factors interact during writing, we looked for the correlations between the variables analysed. 
Table 1.Correlations between analyzed variables

\begin{tabular}{|c|c|c|c|c|c|c|c|}
\hline & $\begin{array}{c}\text { Knowledge } \\
\text { telling }\end{array}$ & $\begin{array}{l}\text { Knowledge } \\
\text { transforming }\end{array}$ & $\begin{array}{l}\text { Knowledge } \\
\text { planning }\end{array}$ & Revision & $\begin{array}{l}\text { Quality } \\
\text { of text }\end{array}$ & Anxiety & confidence \\
\hline $\begin{array}{l}\text { Knowledge } \\
\text { telling }\end{array}$ & - & & & & & & \\
\hline $\begin{array}{l}\text { Knowledge } \\
\text { transforming }\end{array}$ & $-1.00 * *$ & - & . & & & & \\
\hline $\begin{array}{l}\text { Knowledge } \\
\text { planning }\end{array}$ & $-.396^{*}$ & .396 & - & & & & \\
\hline Revision & -1.77 & .177 & .293 & - & & & \\
\hline $\begin{array}{c}\text { Quality of } \\
\text { text }\end{array}$ & $-.353 *$ & -.353 & $.439 *$ & .099 & - & & \\
\hline Anxiety & .151 & -151 & $-.576^{* *}$ & .256 & .082 & - & \\
\hline Confidence & $-.413 *$ & $.413 *$ & $.473 * *$ & $.440 *$ & .351 & $-.384 *$ & - \\
\hline
\end{tabular}

As Table 1 displays, the existence of planning procedures positively correlates both with the feeling of confidence and the quality of the final text. Moreover, students who know and use planning procedures are those who come closer to considering writing as a tool to transform their own knowledge.

On the other hand, lack of planning procedures and, thus, the difficulty of constructing a detailed representation of the task to be solved, involves an increase in the feeling of anxiety and is related with the conception that writing academic texts consists in knowing what one knows or (in the case of empirical studies) what one did.

The rest of correlations support the suggested trend and, in this sense, we must note, as well, the role of revision: the students who revise are those who show more confidence when writing, although this time no significant correlation was found between revision and the quality of the text. This is probably due to the little ability that students show in the revision process and, despite students increasing their expertise as the workshop progresses, this is an activity they are not sufficiently proficient at.

Our third objective asked for the relationship between the regulation of the writing process variables analysed and the quality of the final text. Results show significant differ- 
ences revealing that those students who were able to reflect upon their own voice when writing wrote better texts whilst those who only made syntactic and lexical revisions produced texts of poorer quality $\left(\chi^{2}=8.056\right.$; Kruskal-Wallis $\left.p=.045\right)$. Concerning writing representations, those students who understood that writing implies transforming knowledge wrote better texts (Mann-Whitney U. $=18.00 ; \mathrm{p}=.038$ ) than those who considered writing as an activity to tell their knowledge about the topic (Mann-Whitney $\mathrm{U} .=18.00 \mathrm{p} .=.045$ )

As for the writing process, significant differences were found between those students who devoted effort and time to planning and text quality (Mann-Whitney $U .=18.50 ; p=.033$ ). Nevertheless, the presence of revision did not imply differences in text quality nor in the feelings of anxiety or confidence.

Taking into account these results, and in order to identify those students who were more aware of their process and that had better results in text quality, we decided to make two different groups. Group 1 included students who held a knowledge transforming representation of writing, showed evidences of planning and were concerned with the need to make their own voice visible in their final texts. Group 2, on the other hand, included students who held a knowledge telling representation of writing, did not show evidences of planning and, when revising, were only concerned with the grammatical and lexical correctness of their final texts. As we expected, significant differences in text quality were found, favouring group 1 (MannWhitney $U .=15.00 ; p=.014)$.

Differences in the revision of the different drafts for these two groups were significant for changes in modality (concerning syntax Mann-Whitney $U .=10,00 ; p=.026$; and structure Mann-Whitney $U .=3.00 ; p=.022$ ), and voice (concerning syntax; Mann-Whitney $U .=22.00$; $\mathrm{p}=.011$

Finally, concerning the last objective, we identified those students who made changes regarding modality and structure in all drafts (which showed significant differences), and who were more aware of their difficulties, and those who were the opposite, in order to perform a microanalysis of the decisions they took to regulate their writing process. To perform this microanalysis, we collected all the information related with each subject (survey, diaries, drafts) and we tried to identify those sequences of actions beginning when a problem was identified by the students and they made some specific decisions to solve it. 
We detail these results for two students: the first is representative of group 1 and good in all aspects (A) and the second is representative of group 2 (B). Tables 2 and 3, show the results obtained. It is important to notice that in both cases solutions and changes in drafts were coherent with the difficulties perceived. Nevertheless, student A decided possible solutions for each difficulty while student B did not seem to effect any solution for the perceived difficulties. Finally, the characteristics of the changes introduced in the drafts are also different. In the first case (student A), changes implied adjusting textualization to the constraints of academic texts, to modulating the text structure and the phrasing. In the second case (student B), the changes implied looking for precision (mostly looking for correct and precise words, refining phrases, etc.).

Table 2. Microanalysis of writing regulation. Student A Group 1

\begin{tabular}{|l|l|l|}
\hline $\begin{array}{l}\text { Highly aware of their own process } \\
\text { Comments on structure, control and voice }\end{array}$ & Explicit solutions & Changes in drafts \\
\hline Difficulties & $\begin{array}{l}\text { Lack of important sections } \\
\text { in the text (introductions } \\
\text { and conclusions). Structure } \\
\text { beginning } \\
\text { Taking care of readers and } \\
\text { making explicit comments } \\
\text { to guide them }\end{array}$ & $\begin{array}{l}\text { Changes in Modality- } \\
\text { Structure } \\
\text { Lexical and structural pre- } \\
\text { cision (in all 6 drafts, but } \\
\text { more changes in two last } \\
\text { ones) }\end{array}$ \\
\hline $\begin{array}{l}\text { Be able to identify mistakes } \\
\text { in one's own text and solve } \\
\text { them }\end{array}$ & $\begin{array}{l}\text { Not revising on-line. Delay- } \\
\text { ing revision for the next } \\
\text { day }\end{array}$ & $\begin{array}{l}\text { creasing in each new draft) } \\
\text { Voice }\end{array}$ \\
\hline $\begin{array}{l}\text { Anxiety: focused on writing } \\
\text { con and syntax in the first } \\
\text { drafts and moving to struc- } \\
\text { ture in the last ones }\end{array}$ \\
$\begin{array}{l}\text { conclusions and introduc- } \\
\text { tion }\end{array}$ & $\begin{array}{l}\text { Confront anxiety and revise } \\
\text { in a more structured way: } \\
\text { three levels of revision }\end{array}$ & $\begin{array}{l}\text { Modality increases in each } \\
\text { draft and moves from lexi- } \\
\text { cal changes (first drafts) to } \\
\text { structural changes (last } \\
\text { drafts) }\end{array}$ \\
\hline
\end{tabular}


Table 3. Microanalysis of writing regulation. Student B Group 2

\begin{tabular}{|l|l|l|}
\hline \multicolumn{2}{|l|}{$\begin{array}{l}\text { Awareness of their own process improves with each writing session } \\
\text { Comments on revision mostly focused on grammar and lexic }\end{array}$} \\
\hline \multicolumn{1}{|c|}{ Difficulties } & \multicolumn{1}{c|}{ Explicit solutions } & \multicolumn{1}{c|}{ Changes in drafts } \\
\hline $\begin{array}{l}\text { Need of adjusting to the } \\
\text { characteristics and conven- } \\
\text { tions of academic texts }\end{array}$ & No explicit comments & $\begin{array}{l}\text { Lexical and syntactic precision } \\
\text { (the majority of changes in all } 6 \\
\text { drafts) } \\
\text { Structural precision (more } \\
\text { changes in two last drafts) } \\
\text { Structural Guidance (growing } \\
\text { in each new draft) }\end{array}$ \\
\hline $\begin{array}{l}\text { Be able to identify mistakes } \\
\text { in one's own text and solve } \\
\text { them }\end{array}$ & No explicit comments & $\begin{array}{l}\text { Changes concerning structure } \\
\text { in the first drafts and moving to } \\
\text { lexicon and syntaxes in the last } \\
\text { ones }\end{array}$ \\
\hline $\begin{array}{l}\text { Fear facing some decisions: } \\
\text { subject, research questions }\end{array}$ & No explicit comments & No explicit comments \\
\hline $\begin{array}{l}\text { Anxiety related to writing } \\
\text { workshop (fit the professor's }\end{array}$ & & \\
\hline
\end{tabular}

\section{Discussion and Conclusions}

The results obtained allow us to confirm that consciousness about the process is one of the factors which allow doctoral students to progress in the regulation of their composition process, especially awareness of their own difficulties and possible solutions to solve them. Therefore, in agreement with recent studies (Efklides, 2006), the analyzed results show, on the one hand, that the less conscious students are about their writing process, the more anxious they feel during the process. Moreover, very few students with little consciousness about the process had personal and explicit writing objectives or were able to incorporate new writing regulation strategies to their repertoire.

On the other hand, as some studies have already explained, the more conscious students are, the easier it is for them to produce high quality texts, at the same time as changes in drafts are more coherent with the difficulties they detected and with the possibility to really improve their texts (Graham, 2006). This, together with a clear interest in imposing their own voice on the text translates into being more capable of regulating the writing process or, at least, into exercising a constant control activity over the writing regulation operations. 
It is also this group of students that shows conceptions about writing, which move away from those basically focusing on content or on the formal requirements of the text to the consideration of the epistemic and social function of writing, also in line with the studies on identity we mentioned in the introduction (Ivanic, 1998; Pittard \& Martlew, 2000).

It is important to notice that this notion of identity, which in our study could be linked to the writers' interest for imposing their own voice in text, seems strongly related to selfregulation in writing. Those students who were able to reflect on their voice and worried to make it visible in the text were more aware of their writing process and texts produced qualified as better. Nevertheless, in successive draft revisions, those students revealed more concerned with changes in modality than voice.

We can explain these results arguing that their metalinguistic reflection is linked to those grammatical and structural aspects useful to module text formulation and phrasing or to make progression between paragraphs and sections (Camps \& Milian, 2000). These are aspects that can be understood as related to the possibility to show one's voice in the texts from a rhetoric perspective (Ivanic, 1998), but other discursive and more explicit strategies could be taken into account in order to impose a personal voice to texts (Hyland, 2000). Our students did not seem to be familiar with these explicit strategies -like using first person or impersonal formulations or avoiding some passive expressions favouring active ones ${ }^{3}$.

Concerning affective variables, although anxiety was always present in the students' reports, we did not find significant relationship between this feeling and text quality or specific drafts revision. We can suppose that our students -as volunteer doctoral students- are motivated and interested in improving writing and, despite their negative comments, what they experienced was a kind of nervousness (arousal) which is necessary to manage the writing cognitive load (Hidi \& Boscolo, 2006; Pajares \& Valiante, 2006), but, from our data, we do not know enough about the role that affective variables play in regulation. Based on the microanalyses done, it seems that better students aimed to provide some solutions and strategies to manage their fear and anxiety as well as their cognitive process, but we need more research and some more specific analyses to explore this issue.

\footnotetext{
${ }^{3}$ Passive sentences in Spanish are much less frequent than in English and some students turn to using them in order to avoid their agency
} 
Another question which remains for future studies is related with the possibility to explore more deeply the process followed by those students identified as more aware of their own writing process and able to improve their texts trough revision. We hope that analysing their decisions when they face problems will allow us to better understand how they improve their regulation strategies and their writing.

\section{References}

Bakhtin, M. M. (1952/1986). The problem of Speech genres. In C. Emerson \& M. Holquist (eds.), Speech genres \& other late essays. Austin, TX: University of Texas

Bartels, J.M; Magín-Jackson, S.; \& Kemp, A.D. (2009). Volitional regulation and selfregulated learning: An examination of individual differences in approach-avoidance achievement motivation. Electronic Journal of Research in Educational Psychology, 7 (2), 605-626

Bereiter, C. \& Scardamalia, M. (1987). The psychology of written composition. Hillsdale (N.J.): Erlbaum

Boscolo, P., \& Mason, L. (2001). Writing to learn, writing to transfer. In P. Tynjala, L. Mason, \& K. Lonka (Eds.). Writing as a learning tool: Integrating theory and practice (pp. 83-104). Dordrecht (NL): Kluwer Academic Publishers.

Caffarella, R.S. \& Barnett, B.G. (2000). Teaching doctoral students to become scholarly writers: The importance of Giving and Receiving Critiques. Studies in Higher Education, 25,1, pp. 39-52

Camps, A. \& Castelló, M. (1996). Las estrategias de enseñanza-aprendizaje en la escritura. In C. Monereo \& I. Solé (coords.), El asesoramiento psicopedagógico: una perspectiva profesional y constructivista, (pp. 321-342). Madrid: Alianza

Camps, A. \& Milian, M. (2000). Metalinguistic activity in learning to write. In G. Rijlaarsdam \& E. Esperet (Series Ed.) \& A. Camps \& M. Milian (Eds.) Studies in writing: Vol. 6. Metalinguistic activity in learning to write, (pp. 49-78). Amsterdam: Amsterdam University Press

Carlino, P. (2006). La escritura en la investigación. Escuela de Educación. Series "Documentos de trabajo" no 19. Buenos Aires: Universidad de San Andrés

Castelló, M. (1999). El conocimiento que tienen los estudiantes sobre la escritura. In J.I. Pozo \& C. Monereo (coord.), El aprendizaje estratégico, (pp.197-218). Madrid: Santillana 
Castelló, M. (2000). Students' conceptions on academic writing. In A. Camps \& M. Milian (Eds.), Studies in writing: Vol. 6. Metalinguistic activity in learning to write, (pp. 4978). Amsterdam: Amsterdam University Press

Castelló, M., Iñesta, A.; Miras, M.; Solé, I.; Teberosky, A. \& Zanotto, M. (2007). Escribir y comunicarse en contextos científicos y académicos. Conocimientos y estrategias. Barcelona: Graó

Castelló, M. \& Monereo, C. (1996). Un estudio empírico sobre la enseñanza y el aprendizaje de estrategias para la composición escrita de textos argumentativos. Infancia y aprendizaje, 74, 39-55

Dijk, T.A \& Kintsch, W. (1983). Strategies of discourse comprehension. New York: Academic Press.

Dysthe, O., Samara, A., \& Westrheim, K. (2006). Multivoiced supervision of Master's students: a case study of alternative supervision practices in higher education. Studies in Higher Education, 31(3), 299-318.

Efklides, A. (2006). Metacognition and affect: What can metacognitive experiences tell us about the learning process? Educational Research Review, 1(1), 3-14

Emig, J. (1977). Writing as a mode of learning. College Composition and Communication, $28,122-128$.

Englert, C.S., Mariage, T.V., \& Dunsmore, K. (2006). Tenets of sociocultural Theory in Writing Instruction Research. In C.A. MacArthur, S.Graham \& J. Fitzgerald (eds.), Handbook of Writing Research, pp. 208-221. New York: Guilford Press

Flower, L. \& Hayes, J.R. (1980). The dynamics of composing: Making plans and juggling constraints. In L.W. Gregg \& E.R. Steinberg (eds.), Cognitive processes in writing, (pp.31-50). Hillsdale, N.J. Erlbaum

Flower, L.(2002). Intercultural Knowledge Building: The Literate Action of a Community Think Tank. Writing Selves and Society: Research from Activity Perspectives. Ed. C. Bazerman \& D. Russell. Fort Collins, CO: WAC Clearinghouse $<$ http://wac.colostate.edu/books/selves_societies/>

Graham, S. (2006). Strategy Instruction and the Teaching of Writing: A Meta-Analysis. In C.A. MacArthur, S.Graham \& J. Fitzgerald (eds.), Handbook of Writing Research, (pp. 187-207). New York: Guilford Press

Hidi, S. \& Boscolo, P. (2006). Motivation and writing. En C.A. MacArthur, S.Graham \& J. Fitzgerald (eds.), Handbook of writing research, pp. 144-157. New York: Guilford Press 
Hyland, K. (2000). Disciplinary discourses. Social interactions in academic writing. England, Pearson Education Limited.

Hyland, K. \& Tse, P. (2004). Metadiscourse in academic wirting: A reappraisal. Applied Linguistics, 25(2), 156-177.

Ivanic, R. (1998). The discoursal construction of identity in academic writin. Amsterdam: Benjamins

Lavelle, E. \& Zuercher, N. (2001). The writing approaches of university students. Higher Education, 42, 373-391.

Lonka, K. (1996) How to foster scientific writing in higher education. A workshop in EARLI. Special Interest Group Writing Symposium, Barcelona, Spain, October, 23-25, 1996.

Lonka, K. (2003). Helping doctoral students to finish their theses. In L. Björk, G. Bräuer, L. Rienecker, \& P. S. Jörgensen, (Volume Eds.), Studies in writing, volume 12, Teaching academic writing in European higher education, (113-134), The Netherlands: Kluwer Academic Publisher

MacArthur, C.A., Graham, S., \& Fitzgerald, J. (2006). Handbook of writing research. New York: Guilford Press

Nelson, J. (1990). This was an Easy assignement: Examining how students interpret academic writing tasks. Technical report, No. 43. Eric Information Analysis Products (IAP)

Pajares, F. \& Valiante, G. (2006). Self-Efficacy Beliefs and Motivation in Writing Development. In C.A. MacArthur, S. Graham \& J. Fitzgerald (Eds.), Handbook of writing research, (pp. 158-170). New York: Guilford Press

Pittard, V. \& Martlew, M. (2000). Socially-situated cognition and metalinguistic activity. In A. Camps \& M. Milian (Vol. Eds.), Studies in Writing: Vol. 6. Metalinguistic activity in learning to write, (pp. 79-102). Amsterdam: Amsterdam University Press

Sánchez, E., García, J. N., \& Rio, P. (2002). Escribir es re-escribir. Un análisis de contenidos de los informes realizados a los artículos no publicados en infancia y aprendizaje. Infancia y Aprendizaje. 25, 1, 5-35

Torrano, F. \& González, M.C. (2004). El aprendizaje autorregulado: presente y futuro de la investigación. Electronic Journal of Educational Research, 2(1), 1-34

Tynjäläe, P., Mason, L., \& Lonka, K. (2001). Writing as a learning tool: integrating theory and practice. Boston: Kluwer Academic Publishers

Van Dijkt, T.A. \& Kintsch, W. (1983) Strategies of discourse comprehension. New York: Academic Press 